UDC 351.851:378.1:001.891.3(076.6)

DOI: https://doi.org/10.26661/hst-2020-6-83-07

\title{
QUALITY MANAGEMENT IMPLEMENTATION TECHNIQUE IN EDUCATION: THE CASE OF LITHUANIA
}

\author{
C KNYVIENÉ, INDR' \\ Department of Tourism and Leisure Management, \\ Kaunokolegija/University of Applied Sciences, Lithuania \\ E-mail: indre.knyviene@go.kauko.lt \\ ORCID iD: http://orcid.org/ 0000-0003-0246-2199 \\ Pramonès 20, LT-50468, Kaunas, Литва
}

\begin{abstract}
The relevance of the study: The education system seeks to adapt to market requirements and increase its competitiveness. In order to rise and prosper, educational organizations must use the latest management concepts based on the world's best practices. The philosophy and methods of progress and continuous improvement are presented in the theory of total quality management [20]. Quality management systems in ISO normative documentsprovides possible practical recommendations and requirements for the management of organizations. Thus, the question arises as to how the most appropriate implementation of this standard in educational organizations is whether the ISO quality management system is necessary and applicable to higher education institutions in order to standardize the teaching process and administration.The problem of the researchthe ISO 9000 quality management system was first developed for the manufacturing industry, later developed in the service sector, and is now used in education as well. ISO 9000 in a general sense is a set of principles of good governance, but it is difficult to apply these principles in the process of educational services. Is the quality management system ISO 9000 applicable in the educational organization?The object of the research-operating quality management system ISO 9001: 2000.The aim of the research to theoretically substantiate the possibilities of the quality management system ISO, to learn the attitude of higher education administration and teachers to quality management, to determine the advantages and disadvantages of the quality management system ISO 9001. Methods - Questionnaire survey. Quantitative data analysis.Results.The quality management system ISO 9000 ensures the pursuit of quality policy, standardization of procedures, elimination and avoidance of non-conformities, a system of corrective and preventive actions, and supervision of the quality management system. Quality management system ISO 9000 helps the educational organization to establish itself in the market, helps to meet the customer's requirements. Systematic process management allows processes to be laid out in such a way as to achieve the desired result in the best possible way, ensuring the trust of stakeholders. The quality management standard has significant advantages, such as increased competition in the labor market, better distribution of activities, satisfaction of consumer needs and expectations, and operates effectively at the management level. One of the shortcomings of the system is the cost of certification and maintenance of the system, as well as the staffing approach. The novelty is that it has been tested higher education institutions which have implemented a quality control system.As the result shows that respondents of higher education institutions, assessing the importance of the field of quality management, indicated that the most important area of influence is the external evaluation of the institution, the organizational culture and the improvement of the teaching process. The second most important area of the quality management system is the proper distribution of activities and accreditation of study programs. The advantages of the implemented quality management
\end{abstract}

Quality management implementation technique in education: the case of lithuania 
system ISO 9001 for the activities of the organization were mostly indicated by the respondents as the significantly improved improvement of the study process, as the respondents significantly assessed the creation of the quality team. The most dominant factor highlighting the shortcomings of the quality management system highlighted in this work is the cost of working time. Assessing the shortcomings of the quality management system, respondents expressed the opinion that there is insufficient information about the implementation of ISO in the organization.

Key words: quality, higher institutions, ISO.

Quality management systems in higher education

A quality management system is a mechanism that coordinates and supports the activities required to ensure that the characteristics of products, processes or services meet certain requirements. Quality management is a part of quality management focused on meeting quality requirements[14]; [15]; [16].

'ISO-9000 is a method based on documentation and quality assessment based on consumer satisfaction' [17], [18]. In other words, products and services are developed according to set standards that meet the needs and requirements of consumers. It is important to emphasize that total quality management is not yet a successful implementation of the ISO 9000 series quality assurance standard. Total quality management is a concentrate of human experience in improving the methods of organizing scientific work[22].

According to Omer F. Ozbek[16]: 'The processes of higher education institutions (HEIs) can be evaluated under two major categories: academic and administrative. The functions such as education, training, research, and development are mostly conducted by academicians, whereasfunctions such as student services, resource management, maintenance, and operations are (c) Knyviené, Indré, 2020 conducted by administrative staff. For academic programs, there are regional and global accreditation agencies that set the standards and regulations to ensure quality. Administrative functions, on the other hand, are generally evaluated as business functions of a HEI. While there is a great accumulation of knowledge on academic quality such as curriculum development and research procedures, administrative processes are often overlooked. This chapter provides an overview of quality management in administrative processes of universities and similar higher education institutions, and examines them as service organizations. HEIs have regular business processes such as accounting, finance, and facility management, as well as specific processes such as student enrollment, library, and housing services.'

Examination of the documents governing management systems has shown that all management systems are based on the principle of continuous improvement. The implementation of a quality management system allows the organization to improve further, to strive for continuous improvement, i. implement total quality management [1]; [3]; [4]. Educational quality management is a change management process formed on the basis of quality management. In the initial-quality 
system development and implementation-phase, change management prevails. In the nextstage of quality improvement-in the operation of the quality system-total quality management [23].

Quality has become an important object in global educational organizations. The international quality management standard ISO 9001: 2000 defines quality in general as follows: 'Quality is the degree of compliance of the set of available characteristics with the requirements'[14]; [15]; [16].

By definition, requirements are requirements of all stakeholders (not just the consumer), so this definition can be applied to any type of requirement: technical or nontechnical, such as health, safety, environmental protection, etc., including education. The definition also applies to the results of any process or activity - products, solutions, information, etc.[12] Thus, quality is a term that describes the state of an organization's business results. Everything an organization does directly or indirectly affects the state of business results, so it can be said, and all business goals are related to quality goals. The customer plays a key role in setting requirements, so quality is linked to meeting consumer needs[21].

The direct and main beneficiaries of an educational institution are students. However, they are in many roles at once: they are considered to be a product of the institution after graduation; they are clients of the training process; they are co- participants in the teaching and learning process [19].

'The solution to the problem is further complicated by the fact that students are not the only customers of the high school. Students' parents, firms, prospective employers, teachers and employees, public authorities and politicians in the broadest sense are interested in quality education for society as a whole'[24].

'Educational institutions face enormous tensions in exploiting and adapting market-based quality systems such as ISO 9001. This is driven by an ever-changing environment, globalization, dwindling resources; it is increasingly important for educational institutions to identify the needs of industry, as this requires a more competent workforce'[2].

'Implementing the principles of quality management in a higher education setting is useful and even necessary. The introduction of a quality system would provide an opportunity to streamline the processes taking place in higher education institutions, identify lowquality manifestations, correct and prevent them and systematically improve quality, perform internal quality audits and apply various statistical quality improvement methods. Implementing a quality system in higher education would improve the confidence of students, their prospective employers, research, sponsors, government and other stakeholders that their quality requirements are met' $[10]$.

According to Bevanz-Gonzales[6]: 'Educational organizations around the world start implementing ISO most 
often when faced with growing external pressures for accountability to funders. Although the implementation of this system is successful in the field of production and services, its applicability in the field of education is completely new and therefore poses many problems'.

What determines the successful implementation of ISO 9000 standards? Successfully implemented by those higher education institutions whose managers look favorably on the members of the educational organization, they carry out the implementation of the system themselves and the members of the institution understand the internal processes taking place in the organization[7]; [8]

ISO 9000 standards are not being successfully implemented by those institutions that refuse to implement this system due to frequent system audits due to costs and possible changes in management.

A number of scholars (cit. Kasperavičiūtè-Černiauskienè

Serafinas [11],

e.g. Csizmadia,Enders,\&Westerheijden,20 08; Papadimitriou, 2011; Papadimitriou \& Westerheijden, 2010; Santana, Moreira,Roberto, \& Azambuja, 2010) have examined the factors of ISO 9000 adoption in HEIs.Csizmadia et al. (2008) investigated the influence of organisational characteristics onthe implementation of quality management in Hungarian HEIs based on resource dependency and neoinstitutional theories. Their empirical investigation shows that organisational characteristics (leaders' commitment, external consultants, institutionalreputation and bureaucratic and political decisionmaking processes) have a strongeffect on quality management implementation in Hungarian higher education. Thestudy carried out by Papadimitriou and Westerheijden (2010) seeks to explain isomorphic pressures and the adoption of ISO 9000 standards in HEIs in Greece. They suggest that neo-institutional pressures are important to the adoption of the ISO standard in universities in Greece. Papadimitriou (2011) discusses how leaders (rectors and vice-rectors) in Greek universities perceived external environmental pressures to implement quality management. Results indicate thatquality management in HEIs in Greece is perceived mainly in terms of laws and regulations, and it seems that the Ministry of Education introduced policies to make universities develop formalised management practices.

Based on the ISO 9001 standard, guidelines have been developed for the application of this standard in educational institutions (ISO / IWA2). The IWA2 standard is a criterion for the certification of quality management systems in educational organizations. The requirements of the IWA 2 standard require that an educational organization must anticipate and manage the processes involved in the design, development, delivery process, implementation, and outcome measurement procedures of education. The main parts of the IWA2 standard, as well as the parts of ISO 9001: 2000, are the requirements 
for the quality management system, management responsibility, resource management, product implementation, measurement, evaluation analysis and improvement[9].

Reseach of iso 9001 research on the attitude of higher education institutions to the quality management system

This study also sought to find out what positive effects of the implemented ISO 9001 quality management system and what shortcomings are observed by the respondents. For the respondents, each statement made about the importance of quality management seemed more or less important. The majority of respondents mostly chose the rating "important" (see table 1). Such an approach to the importance of quality management in higher education. Statements as not very important for quality management in ranking were also quite often noted.

Table 1. Choice of respondents' answers

\begin{tabular}{|c|c|c|c|}
\hline $\begin{array}{c}\text { Organization } \\
\text { al culture }\end{array}$ & $\begin{array}{c}\text { For proper } \\
\text { distribution of activities }\end{array}$ & $\begin{array}{r}\text { Institutions for } \\
\text { external evaluation }\end{array}$ & $\begin{array}{c}\text { Accreditation of } \\
\text { study programs }\end{array}$ \\
\hline 77,36 & 75,47 & 83,02 & 73,58 \\
\hline
\end{tabular}

The aspects of the impact of the quality management system ISO 9001 presented in the questionnaire had to be ranked in the following order: 5 significantly improved, 4 significantly improved, 3 - partially improved, 2 - did not improve, 1 - do not know.The highest percentage of respondents $(83.02 \%)$ cited external evaluation of the institution as an important area of quality management. It is clear that for the external evaluator, when assessing the quality assurance, the respondents consider the implemented quality management standard to be an important factor. Their attitude to the importance of accreditation of study programs can be assessed similarly (73.58\%). Thus, it can be concluded that external evaluation is an important element of quality management.

Summarizing the obtained results, it became clear that the most dominant positive aspect of the ISO 9001 system is the impact on the improvement of the study process (see figure 1). 


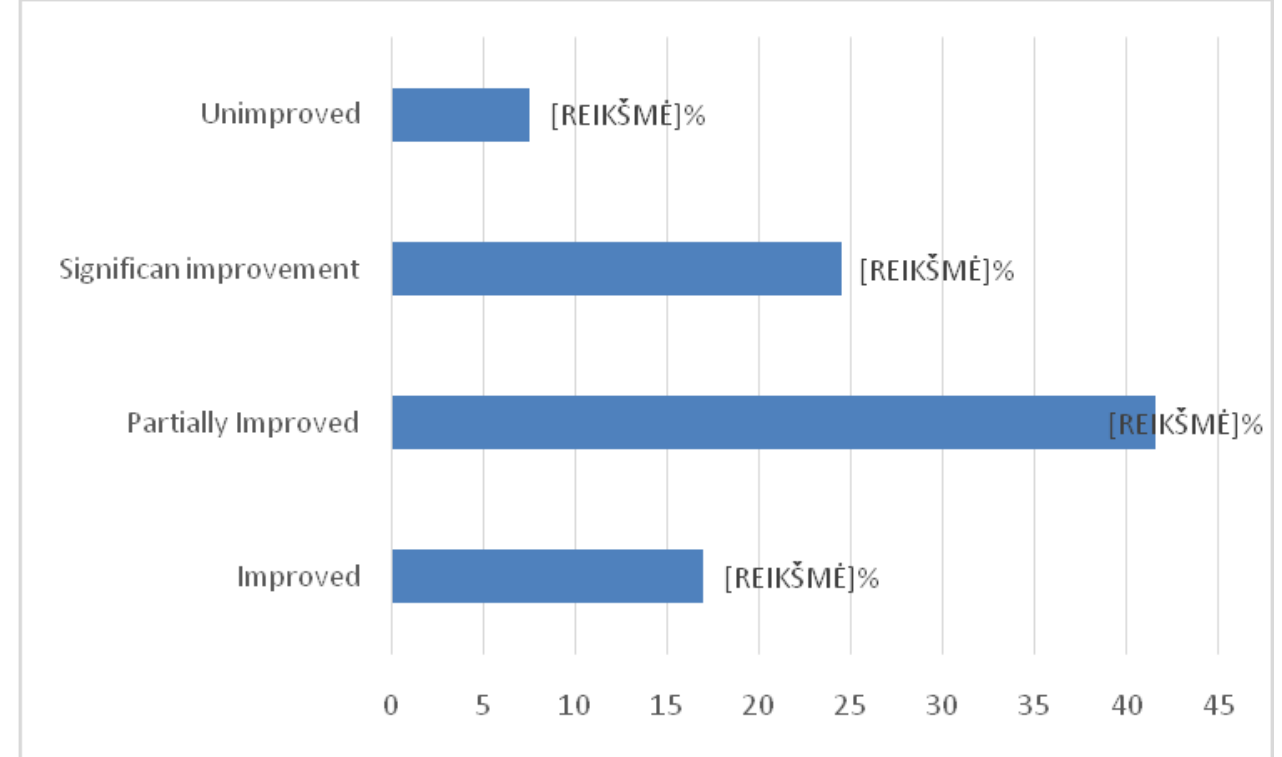

Figure 1. Impact on the improvement of the study process

His rating is $16.98 \%$. As many as $41.51 \%$ of the subjects mentioned it as a partially improved effect, as $24.53 \%$ as a significant improvement. Only $7.55 \%$ of respondents marked it as unimproved. All the respondents expressed their opinion, so I do not know who answered the answers. Thus, meeting consumer needs is the foundation that influences the improvement of the learning process.

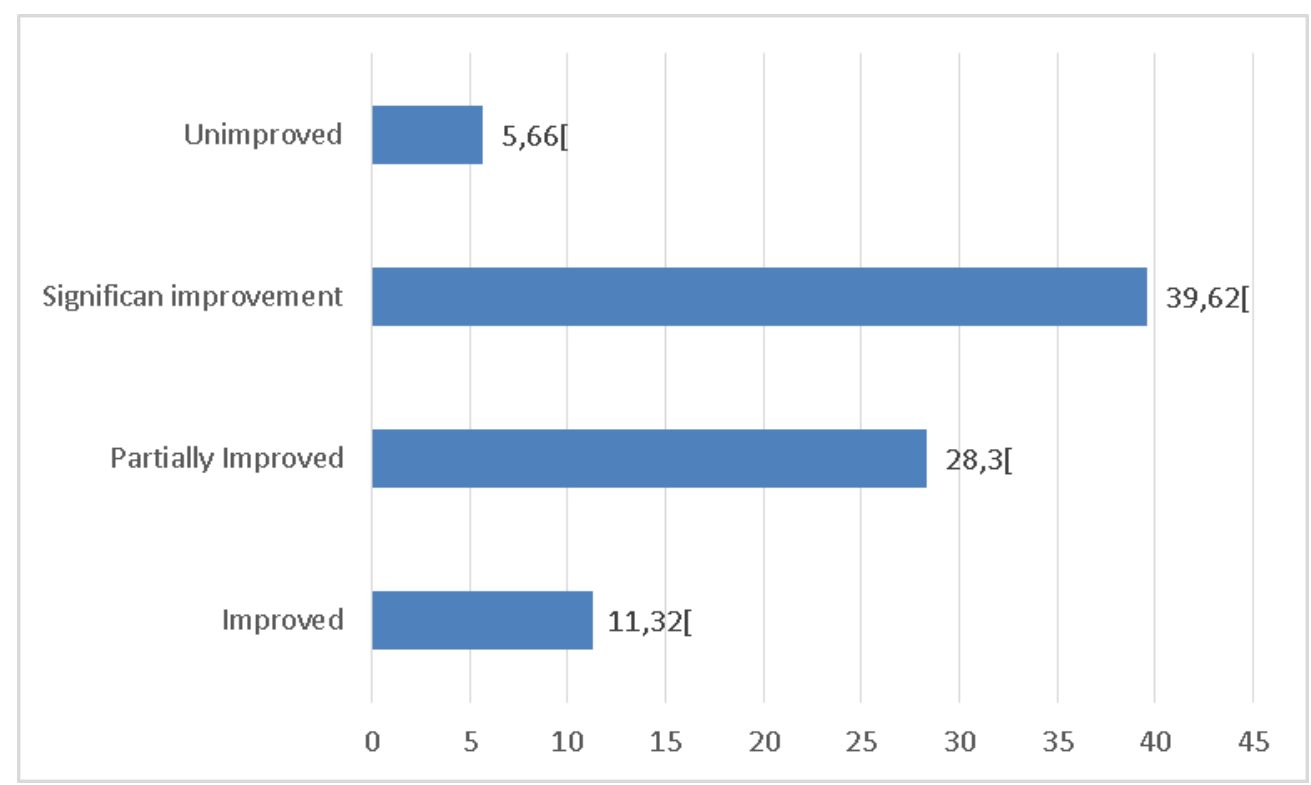

Figure 2. Impact on the efficiency of the quality team

Responding to the question about the impact on the efficiency of the quality team (see figure 2), the respondents based their answers on the fact that a larger part of the respondents $(39.62 \%)$ saw this aspect 
of the organization as a significant improvement, but a large part assessed it as a significant improvement $(11.32 \%)$. Thus, the performance of the quality team, which consists of the audit and internal team, has a significant impact on the quality management system, as its activities are based on the implementation and control of the quality management system according to ISO 9001.

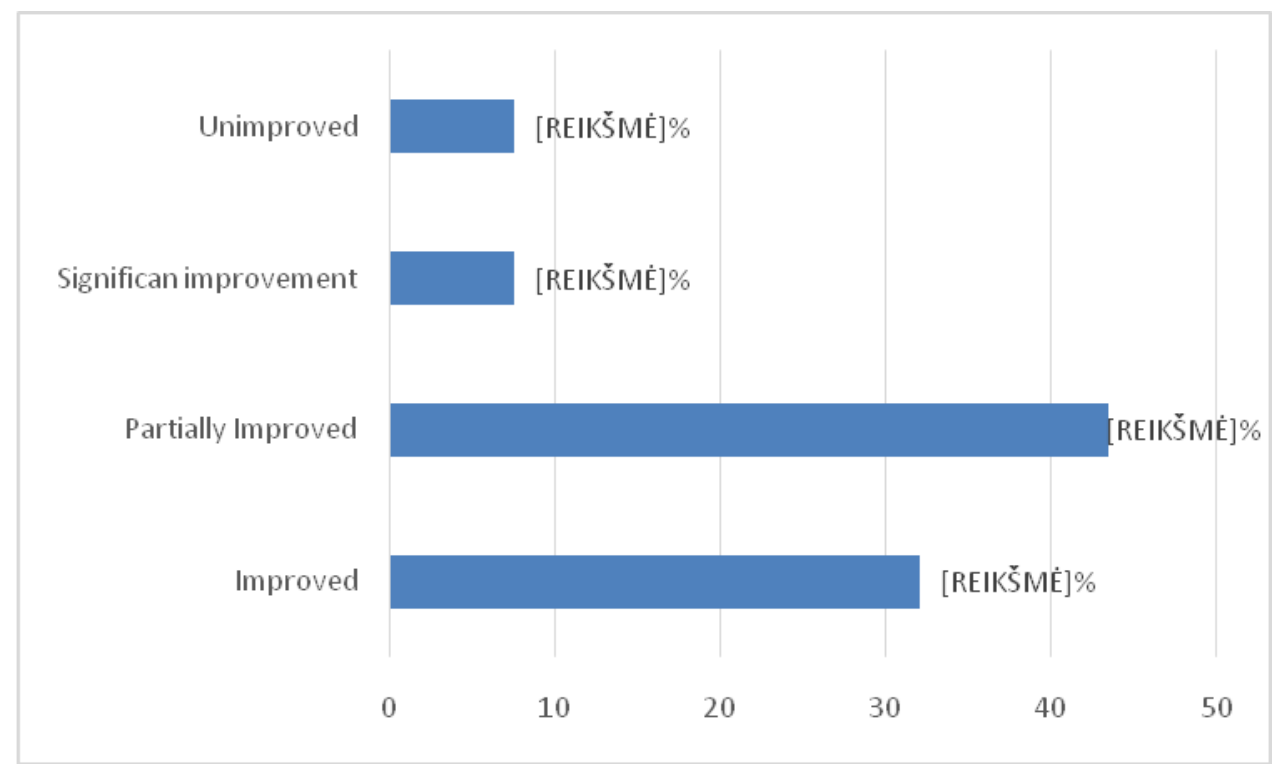

Figure 3.Impact on the study process

The answers of the respondents to the question about the study process (see figure 3) were distributed as follows: significantly improved $7.55 \%$, greatly improved - $32.08 \%$, partially improved $-43.40 \%$, did not improve - $7.55 \%$. Analyzing the answers of the respondents to this question, it can be concluded that the impact of the quality management system on this activity of the organization is not assessed as positive, as a large part of the respondents answered that it has only partially improved. Consequently, the study process is quite complex due to its inertia and is not preferred by the respondents.

Summarizing the aspects of the positive impact of the implemented quality management system ISO 9001, it can be stated that the advantages of this system are assessed by the respondents in most cases positively. In Lithuania, the ISO 9001 quality management system has been implemented in several higher education institutions, so it is assumed that the staff of these schools evaluate the positive impact differently depending on the time of operation, but on average, the most pronounced positive impact is more appropriate distribution of activities and quality team efficiency. assessing the positive impact of the ISO 9001 quality management system.

Summarizing the obtained results, it became clear that the most dominant factor determining the lack of the quality management system ISO 9001 is the cost of working time. $18.87 \%$ of the respondents mentioned it as the most important factor, as 
much as $49.06 \%$ partially agreed with it. $26.42 \%$ of respondents disagreed. Thus, respondents rated the increased "paper" time spent as one of the biggest shortcomings of the ISO quality management system.

Analyzing the respondents 'answers to the question of the application of the quality management system ISO 9001 terminology to education, the respondents' answers were distributed as follows: $37.74 \%$ answered that they do not agree, $28.30 \%$ - partially agree, $13.21 \%$ agree, but a large percentage of respondents $16,98 \%$ - did not have an opinion. Therefore, it can be said that the complexity of the terms of the quality management system ISO 9001 is one of the most important shortcomings in higher education institutions. Respondents were very positive about the possibilities of adapting the quality management system to the teaching process, where as many as $60.38 \%$ of respondents disagreed with the statement that this system is not suitable for organizing the teaching process, although $20.75 \%$ partially agreed and $9.43 \%$ agreed. $7.55 \%$ of respondents did not express an opinion. Thus, it can be stated that the quality management system is adaptable to the study process and functions properly in it.

Lecturers and administrative staff assessed the impact of the quality management system differently. On average, administrative staff see the least impact on the improvement of the teaching process (average 2.51) and the study process (average 2.88), while teachers assess the positive impact as distinguishing between the improvement of the teaching process and identified user needs and expectations 2.59).

Thus, the results of an empirical study showed that:

- The most important area of influence for quality management was the external evaluation of the institution, the appropriate distribution of activities and the improvement of the training process.

- The area of the second most important quality management system is the organizational culture and the improvement of the training process and the appropriate distribution of activities.

- Other quality management areas were identified by respondents as most important or not very important, such as standardization of educational content.

- Respondents rarely chose the quality management area for initiative employee behavior.

Conclusions and recommendations

1) ISO systems have been developed for industry so its applicability to an educational institution is a rather complicated and relatively new phenomenon.

2) The quality management system leads the organization to the perspective of continuous improvement, the purpose of the quality management system is to encourage the development of standards around the world, thus proving the efficiency and productivity of processes. An organization that has been certified may indicate that their system is a documented quality system that is 
accessible to all and consistently and consistently implemented. One of the disadvantages of the system is the cost of certification and the maintenance of this system. Another important drawback is the need for staff, which is the balance between official work and additional work.

3) ISO standards can be implemented in higher education according to the following criteria: user needs, competitive, market needs, procedures ensure quality result, results are measured and developed, discrepancies are eliminated or corrected, effective communication is ensured, further implementation is sought. evidence.

4) The ISO 9000 system is intended for systems and procedures rather than qualitative and academic solutions. The introduction of the ISO standard at the administrative level would make management more understandable, managers would use documents more, and the academic environment, as it is very uneven, as the teaching and learning process itself changes greatly and it is difficult to set requirements and standards. However, quality management standards also have significant advantages, such as increased competition in the labor market, a better distribution of activities, meeting consumer needs and expectations, and effective impact at the management level.

5) ISO / IWA2 is a quality management standard that can be directly applied to educational organizations, and its application needs to be considered. ISO / IWA2 is not translated into Lithuanian, so this standard, which is suitable for educational organizations, is little known.

6) The results of an empirical study showed that: The most important area of influence for quality management was the external evaluation of the institution, the appropriate distribution of activities and the improvement of the training process. The area of the second most important quality management system is the organizational culture and the improvement of the training process and the appropriate distribution of activities. Other quality management areas were identified by respondents as most important or not very important, such as standardization of educational content. Respondents rarely chose the quality management area for initiative employee behavior.

7) The advantages of the implemented quality management system ISO 9001 for the activities of the organization were mainly indicated by the respondents as the significantly improved improvement of the study process, as the respondents significantly assessed the creation of the quality team. He pointed out the study process as partially improved.

8) The most dominant factor highlighting the shortcomings of the quality management system highlighted in this work is the cost of working time.

9) The quality management system is important for the higher education institution, but due to the implementation of the system in terms of time, it is difficult to accept the 
answers of the respondents as complete.

\section{Reccomendations}

1. Higher education institutions that have implemented the quality management standard ISO 9001 evaluate this system as positive, but the guidelines for educational organizations may be ISO / IWA2.

2. According to the results of the performed empirical research, after the implementation of the system, it is important to inform the employees about the progress of the implementation or functioning of the standard. Because the course of compliance with the standards depends on the staff. The less information the high school staff has, the more passive the staff will be during the audit.

\section{СПИСОК ВИКОРИСТАНИХ ДЖЕРЕЛ}

1. Abramavičius, Š., 2001. ISO 9000 serijos standartų ir visuotinès kokybès vadybos santykio problema organizacijos konkurencinio pranašumo igijimo perspektyvos aspektu. Kokybės vadyba - konkurencingo verslo pamatas: respublikinės konferencijos pranešimų medžiaga. 2-37.

2. Adomėnas, V., Jurelionis, J. \& Vaišvila, A., 2005. Vadybos sistemų integravimo ypatumai: respublikinès kokybės vadybos konferencijos pranešimų medžiaga. 16-23.

3. Bernotaite, R., 2002. Kokybès vadybos sistemos įdiegimo pagal ISO 9000:2000 problemos. Kokybès vadyba Lietuvos integracijos į Europos Sajungą procese: respublikinès konferencijos pranešimų medžiaga. 144-146.

4. Belte, J., 2003. Kokybès vadyba pagal ISO standartus. Diegimo ir gyvavimo praktika. Verslo žinių priedas: Strategija ir valdymas. Nr. 4 Lapkritis. 1-8.

5. Berry, G. Towards Quality Systems Development in NSW Public Schools. School Effectiveness ann School Impovement 2002, Vol. 13., No 2, 201-223.

6. Bevans-Gonzales, T. L., 2004. The Strengths and Weekness of I SO 9000 in Vocational Rducation, T.L., Journal of Vocationala Education and Training, Volume 56.

7. Evans, J. R. \& Lindsay, M., 2005. The Management and Control of Quality. 6 e. Thomson.

8. Factors that relase to the successful implementation of ISO 9000 in education : A COMPARISON BETWEEN THE US AND ENGLAND. Thonsauer T.L., 2005

9. ISO/IWA2. (available on Internet www.isoiwa2.sep.gob.mx:8080/iwa2db/apb/?MIval=/iwa2 principal.htm)

10. Karapetrovic, S., Rajamani, D. \& Wilborn, W., 1998. Quality Assurance in Engineering Education: Comparison of Accreditation Schemes and ISO 9001. European Journal of Engeering Education. Jun 98, Vol. 23.

11. Kasperavičiūtè-Černiauskienè, R. \& Serafinas, D., 2018. The adoption of ISO 9001 standard within higher education institutions in Lithuania: innovation diffusions approach. Total Quality Management, vol. 29, No.1. 74-93.

12. Liston, C. Can ISO 9000 Work for the Education Sector? (available at Internet http://www.aair.org.au)

13. LST EN ISO 9000:2001 Kokybès vadybos sistemos. Pagrindai, terminai ir apibrèžimai (ISO 9000:2000). Lietuvos standartizacijos departamentas. Vilnius.

14. LST EN ISO 9001:2001 Kokybès vadybos sistemos. Reikalavimai (ISO 9001:2000). Lietuvos standartizacijos institutas. Vilnius.

15. LST EN ISO 9004:2001 Kokybès vadybos sistemos. Veiklos gerinimas. Rekomendacijos (ISO 9004:2000). Lietuvos standartizacijos institutas. Vilnius. 
16. Manatos, M. J., Sarrico, C. S., \& Rosa, M. J., 2017. The integration of quality management in higher education institutions: A systematic literature review. Total Quality Management \& Business Excellence, 28 (1-2).

17. Stensaker, B., Langfeldt, L., Harvey, L., Huisman, J., \& Westerheijden, D. 2011. An in-depth study on the impact of external quality assurance. Assessment \& Evaluation in Higher Education, 36 (4), 465-478.

18. Van, Damme, D., 2004. Standards and Indicators in Institutional and Programme Accreditation in Higher Education: A Conceptual Framework and a Proposal. In L.Vlăsceanua, L.C.Barrows, (Eds.). Indicators for Institutional and Programme Accreditation in Higher/Tertiary Education. 125-157. Bucharest: UNESCO-CEPES. (available at Internet http://www.cepes.ro/publications/pdf/Indicators/pdf).

19. Van, den Berghe W., 1997. Application of ISO Standarts to Education and Training. Thessaloniki: CEDEFOP.

20. Vanagas, P., 2004. Visuotinès kokybės vadyba. Kaunas,.

21. Vilkas, M., 2005. Kokybės vadybos sistemos:problemos susijusios su igyvendinimu: respublikinès kokybès vadybos konferencijos pranešimų medžiaga. 155-167.

22. West, J., Cianfrani, Ch. A. \& Tsiakals, J. J., 2000. Quality management principles: foundation of ISO 9000:2000 family. Practical application came first. Quality Progress. available at Internet http://www.telebaltika.lt/straipsniai/kokybes_literatura)

23. Woodhouse, D., 1999. Quality and Quality Assurance. Quality and Internationalisation in higher education. Organisation for Economic Co-operation and Development. 225-240.

24. Žekevičienė A., 2001. Visuotinès kokybès vadybos igyvendinimo universitete specifika. Kokybės vadyba - konkurencingo verslo pamatas: respublikinès konferencijos pranešimų medžiaga. $228-233$

\section{References}

1. Abramavičius, Š., 2001. ISO 9000 serijos standartų ir visuotinès kokybès vadybos santykio problema organizacijos konkurencinio pranašumo igijimo perspektyvos aspektu. Kokybės vadyba - konkurencingo verslo pamatas: respublikinės konferencijos pranešimų medžiaga. 2-37.

2. Adomėnas, V., Jurelionis, J. \& Vaišvila, A., 2005. Vadybos sistemų integravimo ypatumai: respublikinès kokybės vadybos konferencijos pranešimų medžiaga. 16-23.

3. Bernotaitè, R., 2002. Kokybès vadybos sistemos įdiegimo pagal ISO 9000:2000 problemos. Kokybės vadyba Lietuvos integracijos ị Europos Sajungą procese: respublikinès konferencijos pranešimų medžiaga. 144-146.

4. Belte, J., 2003. Kokybès vadyba pagal ISO standartus. Diegimo ir gyvavimo praktika. Verslo žinių priedas: Strategija ir valdymas. Nr. 4 Lapkritis. 1-8.

5. Berry, G. Towards Quality Systems Development in NSW Public Schools. School Effectiveness ann School Impovement 2002, Vol. 13., No 2, 201-223.

6. Bevans-Gonzales, T. L., 2004. The Strengths and Weekness of I SO 9000 in Vocational Rducation, T.L., Journal of Vocationala Education and Training, Volume 56.

7. Evans, J. R. \& Lindsay, M., 2005. The Management and Control of Quality. 6 e. Thomson.

8. Factors that relase to the successful implementation of ISO 9000 in education : A COMPARISON BETWEEN THE US AND ENGLAND. Thonsauer T.L., 2005

9. ISO/IWA2. (available on Internet www.isoiwa2.sep.gob.mx:8080/iwa2db/apb/?MIval=/iwa2 principal.htm)

10. Karapetrovic, S., Rajamani, D. \& Wilborn, W., 1998. Quality Assurance in Engineering Education: Comparison of Accreditation Schemes and ISO 9001. European Journal of Engeering Education. Jun 98, Vol. 23.

Quality management implementation technique in education: the case of lithuania 
11. Kasperavičiūtè-Černiauskienè, R. \& Serafinas, D., 2018. The adoption of ISO 9001 standard within higher education institutions in Lithuania: innovation diffusions approach. Total Quality Management, vol. 29, No.1. 74-93.

12. Liston, C. Can ISO 9000 Work for the Education Sector? (available at Internet http://www.aair.org.au)

13. LST EN ISO 9000:2001 Kokybès vadybos sistemos. Pagrindai, terminai ir apibrěžimai (ISO 9000:2000). Lietuvos standartizacijos departamentas. Vilnius.

14. LST EN ISO 9001:2001 Kokybės vadybos sistemos. Reikalavimai (ISO 9001:2000). Lietuvos standartizacijos institutas. Vilnius.

15. LST EN ISO 9004:2001 Kokybès vadybos sistemos. Veiklos gerinimas. Rekomendacijos (ISO 9004:2000). Lietuvos standartizacijos institutas. Vilnius.

16. Manatos, M. J., Sarrico, C. S., \& Rosa, M. J., 2017. The integration of quality management in higher education institutions: A systematic literature review. Total Quality Management \& Business Excellence, 28 (1-2).

17. Stensaker, B., Langfeldt, L., Harvey, L., Huisman, J., \& Westerheijden, D. 2011. An in-depth study on the impact of external quality assurance. Assessment \& Evaluation in Higher Education, 36 (4), 465-478.

18. Van, Damme, D., 2004. Standards and Indicators in Institutional and Programme Accreditation in Higher Education: A Conceptual Framework and a Proposal. In L.Vlăsceanua, L.C.Barrows, (Eds.). Indicators for Institutional and Programme Accreditation in Higher/Tertiary Education. 125-157. Bucharest: UNESCO-CEPES. (available at Internet http://www.cepes.ro/publications/pdf/Indicators/pdf).

19. Van, den Berghe W., 1997. Application of ISO Standarts to Education and Training. Thessaloniki: CEDEFOP.

20. Vanagas, P., 2004. Visuotinès kokybės vadyba. Kaunas,.

21. Vilkas, M., 2005. Kokybès vadybos sistemos:problemos susijusios su įgyvendinimu: respublikinès kokybès vadybos konferencijos pranešimų medžiaga. 155-167.

22. West, J., Cianfrani, Ch. A. \& Tsiakals, J. J., 2000. Quality management principles: foundation of ISO 9000:2000 family. Practical application came first. Quality Progress. available at Internet http://www.telebaltika.lt/straipsniai/kokybes_literatura)

23. Woodhouse, D., 1999. Quality and Quality Assurance. Quality and Internationalisation in higher education. Organisation for Economic Co-operation and Development. 225-240.

24. Žekevičienė A., 2001. Visuotinès kokybès vadybos igyvendinimo universitete specifika. Kokybės vadyba - konkurencingo verslo pamatas: respublikinès konferencijos pranešimų medžiaga. 228-233

КНІВЕНЕ, ІНДРЕ - лектор, Каунаський університет прикладних наук (Каунас, Литва)

E-mail: indre.knyviene@go.kauko.lt.

ORCID iD: http://orcid.org/ 0000-0003-0246-2199

\section{МЕТОД УПРОВАДЖЕННЯ УПРАВЛІННЯ ЯКІСТЮ ОСВІТИ: ПРИКЛАД ЛИТВИ}

Актуальність дослідження: система освіти прагне адаптуватися до вимог ринку і підвищити свою конкурентоспроможність. Щоб рости і процвітати, освітні організації повинні використовувати новітні концепції управління, засновані на кращих світових практиках. Філософія і методи прогресу і постійного поліпшення представлені в теорії загального управління якістю [20]. Системи менеджменту якості у нормативних 
документах ISO містять можливі практичні рекомендації та вимоги до менеджменту організацій. Таким чином, виникає питання, яким чином найбільш підходяща реалізація цього стандарту в освітніх організаціях полягає в тому, чи необхідна система менеджменту якості ISO і може бути застосована вона до вищих навчальних закладів для стандартизації процесу навчання i та адміністрації. Проблема дослідження. Система менеджменту якості ISO 9000 була спочатку розроблена для обробної промисловості, пізніше була розроблена у сфері послуг, а тепер використовується також в освіті. ISO 9000 у загальному розумінні являє собою набір принципів належного врядування, але ці принципи складно застосувати у процесі надання освітніх послуг. Чи застосовується система менеджменту якості ISO 9000 в освітній організації? Мета дослідження: теоретично обгрунтувати можливості системи менеджменту якості ISO, вивчити ставлення адміністрації вищої освіти і викладачів до менеджменту якості, визначити переваги. і недоліки системи менеджменту якості ISO 9001. Методи анкетне опитування, кількісний аналіз даних. Отримані результати. Система менеджменту якості ISO 9000 забезпечує дотримання політики якості, стандартизацію процедур, усунення та запобігання невідповідностей, систему коригувальних i запобіжних дій і нагляд за системою менеджменту якості. Система менеджменту якості ISO 9000 допомагає освітньої організації утвердитися на ринку, допомагає відповідати вимогам замовника. Систематичне управління процесами дозволяє вибудовувати процеси таким чином, щоб досягти бажаного результату найкращим чином, забезпечуючи довіру зацікавлених сторін. Стандарт менеджменту якості має значні переваги, такі як посилення конкуренції на ринку праці, кращий розподіл видів діяльності, задоволення потреб та очікувань споживачів, і ефективно діє на рівні управління. Одним 3 недоліків системи $є$ вартість сертифікації і обслуговування системи, а також кадровий підхід. Висновок. Респонденти вищих навчальних закладів, оцінюючи важливість галузі управління якістю, вказали, що найбільш важливою сферою впливу $є$ зовнішня оцінка вузу, організаційна культура i поліпшення навчального процесу. Друга за важливістю область системи менеджменту якості - це правильний розподіл діяльності та акредитація освітніх програм. Переваги впровадженої системи менеджменту якості ISO 9001 для діяльності організації респонденти найчастіше вказали як значно покращився поліпшення навчального процесу, так як респонденти істотно оцінили створення команди якості. Найбільш домінуючим фактором, що підкреслює недоліки системи менеджменту якості, виявлені у цій роботі, $є$ вартість робочого часу. Оцінюючи недоліки системи менеджменту якості, респонденти висловили думку, що інформації про впровадження ISO в організації недостатньо.

Ключові слова: якість, вищі навчальні заклади, ISO.

КНИВЕНЕ, ИНДРЕ - лектор, Каунасский $\quad$ университет $\quad$ прикладных $\quad$ наук (Каунас, Литва)

E-mail : indre.knyviene@ go.kauko.lt.

ORCID iD: http://orcid.org/ 0000-0003-0246-2199

\section{МЕТОД ВНЕДРЕНИЯ УПРАВЛЕНИЯ КАЧЕСТВОМ ОБРАЗОВАНИЯ: ПРИМЕР ЛИТВЫ}

Актуальность исследования: система образования стремится адаптироваться к требованиям рынка и повысить свою конкурентоспособность. Чтобы расти и процветать, образовательные организации должны использовать новейшие концепции управления, основанные на лучших мировых практиках. Философия и методы прогресса и постоянного улучшения представлены в теории всеобщего управления 
качеством [20].Системы менеджмента качества в нормативных документах ISO содержат возможные практические рекомендации и требования к менеджменту организаций. Таким образом, возникает вопрос, каким образом наиболее подходящая реализация этого стандарта в образовательных организациях заключается в том, необходима ли система менеджмента качества ISO и применима ли она к высшим учебным заведениям для стандартизации процесса обучения и и администрация. Проблема исследования. Система менеджмента качества ISO 9000 была сначала разработана для обрабатывающей промышленности, позже была разработана в сфере услуг, а теперь используется также в образовании. ISO 9000 в общем смысле представляет собой набор принципов надлежащего управления, но эти принципы сложно применить в процессе предоставления образовательных услуг. Применяется ли система менеджмента качества ISO 9000 в образовательной организации? Цель исследования: теоретически обосновать возможности системы менеджмента качества ISO, изучить отношение администрации высшего образования и преподавателей к менеджменту качества, определить преимущества. и недостатки системы менеджмента качества ISO 9001. Методы - Анкетный опрос. Количественный анализ данных. Полученные результаты. Система менеджмента качества ISO 9000 обеспечивает соблюдение политики качества, стандартизацию процедур, устранение и предотвращение несоответствий, систему корректирующих и предупреждающих действий и надзор за системой менеджмента качества. Система менеджмента качества ISO 9000 помогает образовательной организации утвердиться на рынке, помогает соответствовать требованиям заказчика. Систематическое управление процессами позволяет выстраивать процессы таким образом, чтобы достичь желаемого результата наилучшим образом, обеспечивая доверие заинтересованных сторон. Стандарт менеджмента качества имеет значительные преимущества, такие как усиление конкуренции на рынке труда, лучшее распределение видов деятельности, удовлетворение потребностей и ожиданий потребителей, и эффективно действует на уровне управления. Одним из недостатков системы является стоимость сертификации и обслуживания системы, а также кадровый подход. Заключение. Респонденты высших учебных заведений, оценивая важность области управления качеством, указали, что наиболее важной сферой влияния является внешняя оценка вуза, организационная культура и улучшение учебного процесса. Вторая по важности область системы менеджмента качества - это правильное распределение деятельности и аккредитация образовательных программ. Преимущества внедренной системы менеджмента качества ISO 9001 для деятельности организации респонденты чаще всего указали как значительно улучшившееся улучшение учебного процесса, так как респонденты существенно оценили создание команды качества. Наиболее доминирующим фактором, подчеркивающим недостатки системы менеджмента качества, выявленные в этой работе, является стоимость рабочего времени. Оценивая недостатки системы менеджмента качества, респонденты выразили мнение, что информации о внедрении ISO в организации недостаточно.

Ключевые слова: качество, высшие учебные заведения, ISO.

Received date 06. 12.2020

Accepted date 16.12.2020

Published date 20.12.2020 